\title{
Spatio-temporal variation in mortality rates of White-chinned Petrels Procellaria aequinoctialis interacting with longliners in the south-west Atlantic
}

\author{
AGUSTINA GÓMEZ LAICH and MARCO FAVERO
}

\section{Summary}

The White-chinned Petrel Procellaria aequinoctialis is the second most commonly captured species by Argentinean longliners. The severe declines that this species has experienced in some of its populations (e.g. South Georgia Islands) have been principally attributed to incidental mortality associated with longliners. In this study we analyse the spatio-temporal variability in the mortality rates of White-chinned Petrels on the Patagonian Shelf and the effects that environmental and operational variability have on such mortality. The average capture rate $( \pm I$ SD) for the period 1999-2003 was 0.014 \pm 0.090 White-chinned Petrels for every 1,000 hooks deployed. Higher capture rates were observed when short longlines were deployed. Capture rates were not affected by the wind speed or by the time to the full moon. The distribution of the captures differed throughout the year. During autumn-winter most captures took place in the north of the Patagonian Shelf, whereas during spring-summer incidental captures occurred principally to the south between $45^{\circ} \mathrm{S}$ and $50^{\circ} \mathrm{S}$.

\section{Resumen}

El Petrel Barba Blanca Procellaria aequinoctialis constituye la segunda especie más frecuentemente capturada por la flota palangrera Argentina. Los importantes decrecimientos poblacionales observados en algunas poblaciones de esta especie (e.g. Islas Georgias del Sur) han sido principalmente atribuidos a la mortalidad incidental asociada a embarcaciones palangreras. En este trabajo se analizó la variación espacio- temporal en las tasas de captura incidental del Petrel Barba Blanca a lo largo de la Plataforma Continental Argentina y se estudió el efecto que diferentes variables ambientales y operacionales tienen sobre la mortalidad incidental de esta especie. La tasa de captura promedio ( \pm d.s) durante el periodo $1999-2003$ fue de $0.014 \pm 0.090$ Petreles Barba Blanca cada 1.000 anzuelos. Mayores tasas de captura fueron registradas al utilizar palangres cortos. No se observó un efecto de la intensidad del viento ni de la distancia a la luna llena sobre las tasas de captura. La distribución de las capturas difirió a lo largo del año. Durante el otoño-invierno la mayoría de las capturas estuvieron localizadas al norte de la Plataforma Continental Argentina, mientras que durante los meses de primavera-verano las capturas estuvieron localizadas principalmente entre los $45^{\circ} \mathrm{S}$ y $50^{\circ} \mathrm{S}$.

\section{Introduction}

Recently, there has been increasing concern about the effects that longline fisheries may have on various species of albatrosses and petrels (Alexander et al. 1997). Although longlining is thought 
to be a very selective and conservation-oriented fishing method, many seabirds are incidentally caught. When longlines are set, the baited hooks may remain near the surface for a short while before they start sinking. It is during this time that they become available to seabirds (Løkkeborg 1998). In some areas, not only seabird mortality is of great concern but also the associated bait loss and the consequent reduction in the effectiveness of the fishing method (Løkkeborg 1998). The two most frequently captured species worldwide are the Black-browed Albatross Thalassarche melanophrys and the White-chinned Petrel Procellaria aequinoctialis (Kock 2001).

The White-chinned Petrel is one of the most widely distributed petrels and probably the most abundant of the four species of the genus (Warham 1990). During the breeding season, this medium-sized petrel makes some of the longest foraging journeys of any seabird, reaching distances of about $3,500 \mathrm{~km}$ from the colony (Weimerskirch et al. 1999). The bird's wide foraging range and diverse diet, together with its diving abilities, substantially increase the risk of mortality associated with longline fisheries (Huin 1994, Berrow and Croxall 1999, Weimerskirch et al. 1999).

White-chinned Petrels breeding on the South Georgia Islands use the Patagonian Shelf as a foraging area both during the breeding and non-breeding seasons (Berrow et al. 20oob). During the last 20 years, South Georgia's White-chinned Petrel population decreased by $28 \%$ (Berrow et al. 2000a) and this reduction was partially attributed to incidental mortality associated with longline fisheries operating in waters off the South Georgia Islands, South Africa and South America (Weimerskirch et al. 1999, Berrow et al. 200ob). The inferred steep declines of this species especially due to mortality in longline fisheries have led to the classification of the White-chinned Petrel as Vulnerable by the IUCN (Birdlife International 2004).

In Argentina, White-chinned Petrels are frequently caught by longliners operating on the Patagonian Shelf and shelf-break (Favero et al. 2003). Incidental captures of this species have also been reported all along the south-west Atlantic in waters off Uruguay and Brazil (Neves and Olmos 1997, Olmos et al. 2000). The objectives of this study were to analyse (I) the seasonal distribution of White-chinned Petrel captures along the Patagonian Shelf and (2) the effect of operational and environmental variability on the incidental mortality of this species.

\section{Materials and methods}

During the study period (1999-2003), the number of Argentinean longline vessels operating on the continental shelf and shelf-break ranged from five to eleven, with an annual average fishing effort of c. $30 \times 106$ hooks. During 1999 and 2000, four of the vessels used the Spanish method while the others used the autoline method (data estimated from the analysed fishing reports). Since 2001, all longliners have used the autoline method. These two methods differ in that while in the Spanish method two lines are deployed (one being the fishing line and the other an auxiliary line) and the hooks are baited manually, in the autoline method a single line is set and the hooks are baited automatically. The demersal longline fisheries operating on the Argentinean shelf and shelf-break during the study period targeted Patagonian Toothfish Dissostichus eleginoides and Yellownose Skate Dipturus chilensis. A semi-pelagic longline fishery targeted Kingclip Genypterus blacodes.

The data on incidental mortality of seabirds were collected by observers from the National Observers Programme of the Instituto Nacional de Investigación y Desarrollo Pesquero (INIDEP, National Institute of Fisheries Research and Development) on board freezer longliners. Incidental mortality was quantified in terms of the number of White-chinned Petrels killed for every 1,000 hooks deployed (hereafter capture rate). No information about the gender or ageclass composition of the caught birds was available in the fishing reports. The spatio-temporal variation in mortality was determined by grouping the data into two seasons: spring-summer 
(21 September to 21 March) and autumn-winter (22 March to 20 September). Maps were generated by overlaying incidental White-chinned Petrel capture rates with the seasonal spatial distribution of the fishing effort.

The position, date, time and number of hooks of every line setting were recorded. Wind intensity for each setting event was obtained from satellite images (scatterometer) available at the National Oceanic and Atmospheric Administration (NOAA) website (http://orbit212.wwb.noaa.gov/cgi-bin/qscat_arch.pl?year=\&day=). The wind intensity was divided into six categories scaled every 5 knots $(\leqslant 5,6-10,11-15,16-20,21-25$, $>25$ knots).

Nautical twilight was used to determine day and night settings. Longline length effect was analysed by considering the number of hooks deployed per setting. Longlines were divided into three categories: <10,001 hooks, 10,001-20,000 hooks and >20,001 hooks).

To analyse the effect of operational and environmental factors on the capture rates of Whitechinned Petrel, Mann-Whitney and Kruskal-Wallis tests were performed. In these analyses, only the settings in which at least one bird had been caught were considered.

Additionally, a generalized linear model (GLM) was used to examine how the probabilities of capturing at least one bird during each particular setting (i.e. chance of mortality) varied with changes in the wind intensity, time to the full moon and day-night settings. In this analysis, the response variable had two possible values: o if no bird was caught in a particular setting, or $I$ if at least one bird was caught. GLMs with a logit link function and binomial response distribution (McCullagh and Nelder 1983) were used to fit the bird catch probability in relation to the following categorical variables: wind intensity (6 levels), day-night setting (2 levels) and time to the full moon ( 5 levels). To perform this analysis, the total number of settings with capture and an equivalent number of randomly chosen settings without capture from the whole dataset were considered. Parameter estimates with a positive value indicate an increase in the chance of capturing a bird, while those with a negative value indicate a decrease. The rate of change represents the likelihood of an event occurring under one given condition compared with the likelihood of the same event occurring under another condition (Klaer and Polacheck 1998).

\section{Results}

The total number of White-chinned Petrels reported to have been incidentally caught by Argentinean longliners operating on the Patagonian Shelf and shelf-break during the analysis was 251. The average ( \pm I SD) capture rate was $0.014 \pm 0.090$ White-chinned Petrels per 1,000 hooks. The distribution of the captures varied between the seasons. During autumn-winter, White-chinned Petrel captures were principally distributed to the north of the shelf-break $\left(36^{\circ}-\right.$ $\left.41^{\circ} \mathrm{S}\right)$ and by the Burwood Bank, East of Staten Island $\left(c .55^{\circ} \mathrm{S}\right)$, and mostly associated with the Patagonian Toothfish fishery (Figure IA). Incidental mortalities observed during springsummer were concentrated on the central Patagonian Shelf $\left(44^{\circ}-49^{\circ} \mathrm{S}\right)$ and associated with longliners targeting Toothfish and Kingclip (Figure $1 \mathrm{~B}$ ).

Capture rates were significantly affected by the length of the lines, with highest mortalities observed when short lines (i.e. holding $>_{10,000}$ hooks) were deployed (Kruskal-Wallis $\mathrm{H}_{2,125}=$ 6o.8; $P<$ o.001) (Figure 2A).

Higher capture rates were observed during day settings (Mann-Whitney $U$-test $Z=8.69 ; P<$ 0.001) (Figure $2 \mathrm{~B}$ ). When the chance of mortality was analysed, no significant effect of the setting time was observed $\left(\chi^{2}{ }_{1}=0.16 ; P=0.69\right.$ ) (Table 1 ).

No significant effect of the phase of the moon was observed either on the mortality rate (Kruskal-Wallis $\left.H_{4,74}=1.45 P=0.84\right)$ or on the chance of mortality $\left(\chi^{2}{ }_{4}=1.83 ; P=0.77\right)$ (Table 1 ). No effect of wind speed was observed in any of the analyses performed (KruskalWallis $H_{5,125}=6.27, P=0.28 ; \chi^{2}{ }_{5}=8.82, P=0.12$ ) (Figure $2 \mathrm{C}$; Table 1 ). 


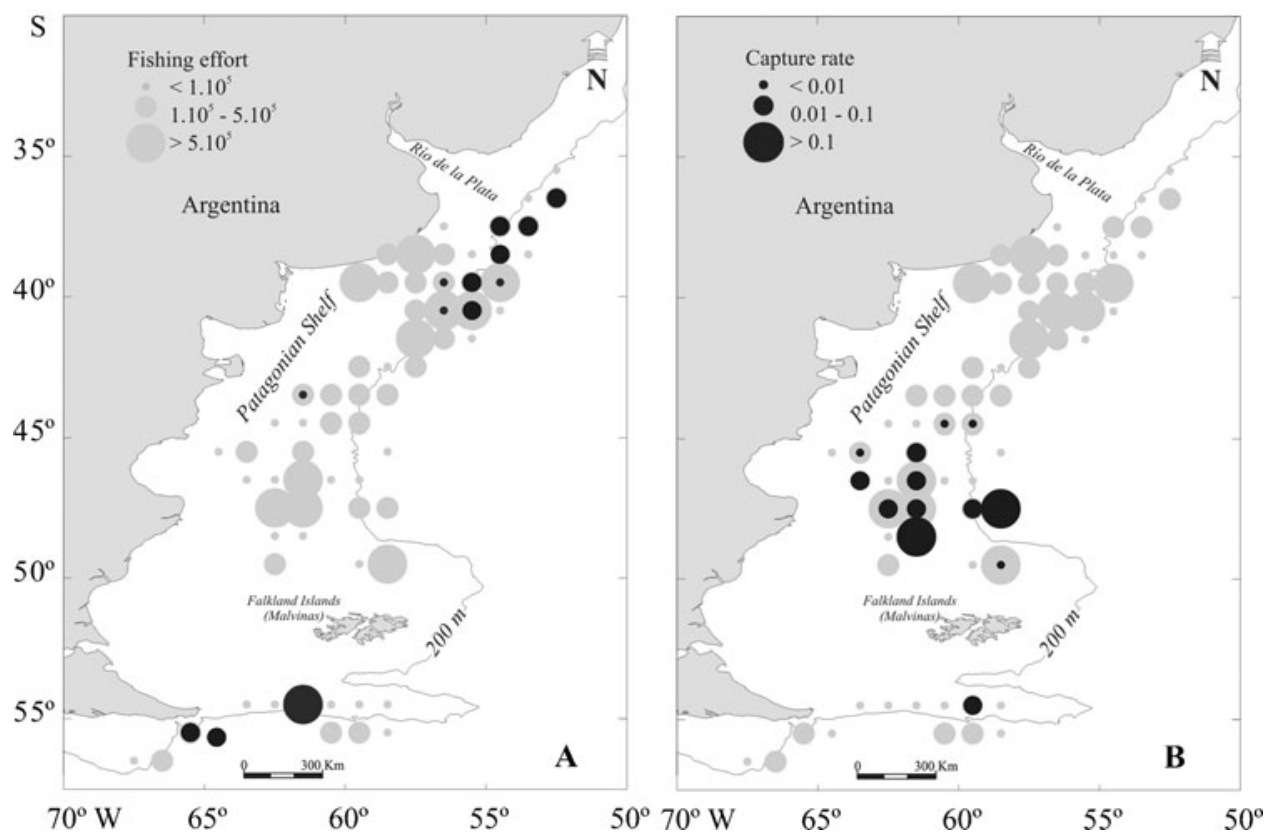

Figure 1 . Distribution of the fishing effort and mortality of White-chinned Petrels along the Patagonian Shelf during austral autumn-winter $(A)$ and spring-summer $(B)$ seasons. Capture rates are expressed as the number of White-chinned Petrels caught per 1,00o hooks deployed.

\section{Discussion}

White-chinned Petrels are frequently caught by Argentinean longliners operating on the Patagonian Shelf. Although the capture rate reported in this study is relatively low, it may be considered a low estimate, since reporting the incidental capture of seabirds is not mandatory for Argentinean fishing observers (hence lack of information is suspected). Moreover, in some cases seabirds can be partly or completely eaten by fish or they can be torn off from the hooks during line hauling, reducing the number of seabirds reported (Brothers 1991).

The general distribution of the captures, principally to the north of the Patagonian Shelf during autumn-winter and to the south during spring-summer, was in agreement with previous studies. During winter months, South Georgia White-chinned Petrels have been observed making extensive use of the Patagonian Shelf, with most of their activity concentrated in the more northerly region (Phillips et al. 2006). Moreover, during autumn and winter greater numbers of White-chinned Petrels have been observed attending longliners off the coast of Brazil and Uruguay (Olmos et al. 200o). In contrast, during spring-summer, satellite tracking studies reveal that breeding White-chinned Petrels from South Georgia travel to the Patagonian Shelf and feed around Malvinas-Falkland Islands, the Patagonian shelf-break and sub-Antarctic waters (Weimerskirch et al. 1999, Berrow et al. 200ob, Phillips et al. 2006). During the springsummer season, highly productive areas have been registered on the Patagonian Shelf (e.g. upwellings along the shelf-break front and Peninsula Valdes tidal front; Acha et al. 2004). These areas are frequented both by Argentinean longliners and White-chinned Petrels breeding in South Georgia (Berrow et al. 20oob), and should be considered as potentially critical areas where interaction with fishing vessels is very likely to occur. Although the seasonal changes in the distribution of White-chinned Petrel captures are in agreement with the seasonal movements of 

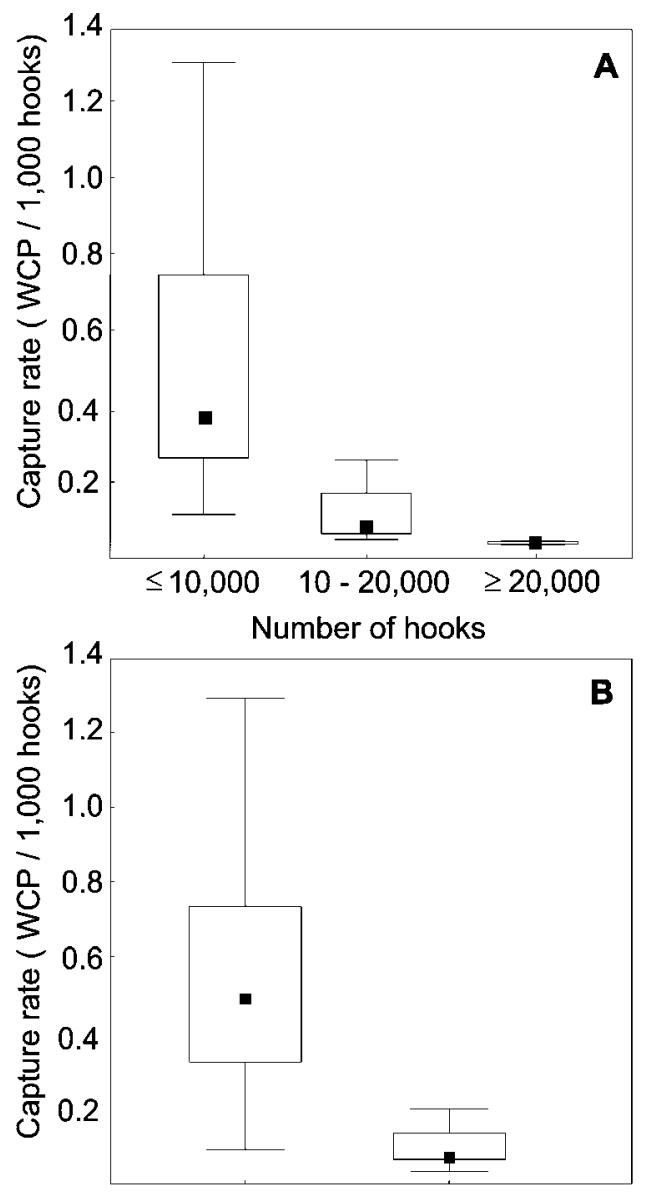

Day settings Night settings

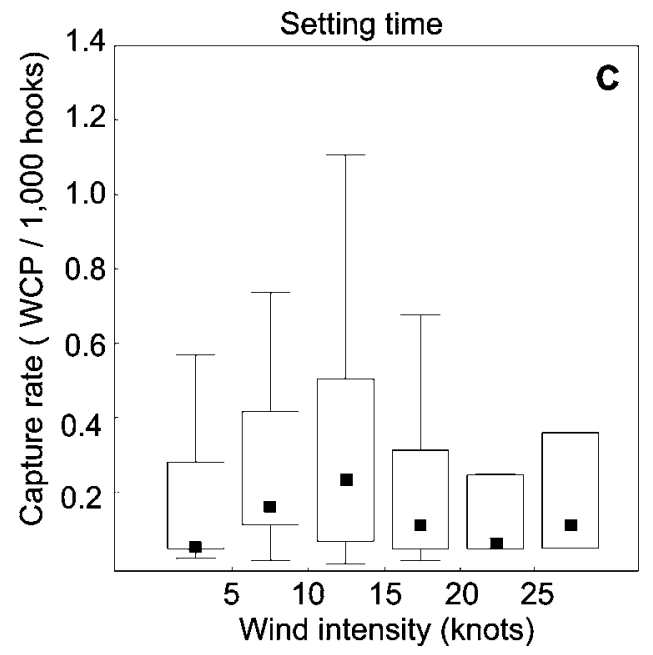

Figure 2. Effect of longline length $(A)$, day or night setting $(B)$ and wind intensity $(C)$ on the capture rate of White-chinned Petrels (WCP). Median values (squares) are given with $25 \%$ and $75 \%$ percentiles (boxes) and range (whiskers). 
Table 1. Parameter estimates produced by the models using single explanatory variables to investigate relationships between the environmental variables and the chance of capturing a bird during a line set, standard error (SE), rate of change in odds (calculated as the anti-log of the parameter estimates) and $95 \%$ confidence limits of the change in odds $( \pm 2$ SE).

\begin{tabular}{|c|c|c|c|c|c|c|}
\hline Variable & Measure & $\begin{array}{l}\text { Parameter } \\
\text { estimate }\end{array}$ & SE & $\begin{array}{l}\text { Rate of } \\
\text { change in } \\
\text { odds }\end{array}$ & $\begin{array}{l}95 \% \\
\text { confidence } \\
\text { limits }\end{array}$ & $\chi^{2}$ \\
\hline \multirow{7}{*}{$\begin{array}{l}\text { Wind speed } \\
\text { (knots) }\end{array}$} & & & & & & 8.82 \\
\hline & $\leqslant 5$ & -0.28 & 0.29 & 0.76 & $0.42-1.36$ & \\
\hline & 6-10 & 0.10 & 0.23 & 1.11 & $0.70-1.74$ & \\
\hline & $11-15$ & -0.38 & 0.23 & 0.68 & $0.43-1.09$ & \\
\hline & $16-20$ & -0.43 & 0.23 & 0.65 & $0.41-1.03$ & \\
\hline & $21-25$ & -0.01 & 0.33 & 0.99 & $0.5^{2-1.91}$ & \\
\hline & $\geqslant 25$ & & & & & \\
\hline \multirow[t]{2}{*}{ Setting time } & & & & & & 0.16 \\
\hline & Day Night & 0.05 & 0.11 & 1.05 & $0.83-1.32$ & \\
\hline \multirow{6}{*}{$\begin{array}{l}\text { Time to the full } \\
\text { moon (days) }\end{array}$} & & & & & & 1.83 \\
\hline & $\leqslant 2$ & 0.03 & 0.27 & 1.03 & $0.60-1.77$ & \\
\hline & $3-5$ & -0.24 & 0.28 & 0.79 & $0.45-1.38$ & \\
\hline & $6-8$ & -0.01 & 0.30 & 0.99 & $0.54-1.81$ & \\
\hline & $9^{-11}$ & -0.12 & 0.29 & 0.89 & $0.50-1.59$ & \\
\hline & $12-14$ & & & & & \\
\hline
\end{tabular}

this species along the Patagonian Shelf, it should be considered that the changes observed in the distribution of captures cannot be attributed to the distribution patterns of the species alone, since the fishing effort was not uniformly distributed through the year.

The significant effect of the length of longlines on White-chinned Petrel mortality rates was in agreement with that observed by Argentinean longliners on the Black-browed Albatross (Gómez Laich et al. 2006). This result has not been addressed in other fisheries. Shorter longlines were principally used in autumn, which coincides with the season in which higher capture rates were observed. We suggest that the longline length effect may be related to differences in the sink rates between different equipment, an issue that is currently under exploration in the local fishery.

Although capture rates were higher during day settings, no difference was observed in the chance of mortality between day and night settings. The difference in the results obtained in the two analyses could be explained by the fact that when the capture rates were analysed all the birds killed in a particular setting were considered while when the chance of mortality was analysed no distinction was made if one or more birds were caught in a particular setting. The fact that the chance of mortality did not differ between day and night settings is in accordance with previous studies that report White-chinned Petrels attempting to feed on baits during night settings (Ashford et al. 1995, Cherel et al. 1996, Barnes et al. 1997, Robertson et al. 2006). Although night setting is a proposed mitigation method (Brothers et al. 1999) to prevent the incidental mortality of White-chinned Petrels, this method should be implemented in combination with others (e.g. streamer line). With reference to the effect of the phase of the moon, our results agree with studies on White-chinned Petrel in which no influence of the phase of the moon on the foraging activity was observed (Weimerskirch et al. 1999). However, the lack of data on sky cloudiness limits the interpretation of these results.

The incidental mortality of White-chinned Petrels associated with longliners may be one of the most important causes of its population reductions. The information presented in this study is important for the future development and implementation of mitigation measures. The 
determination of critical areas along the continental shelf and shelf-break where White-chinned Petrels and fishing activities converge is crucial to the conservation of this species. The combination of different mitigation measures such as the employment of streamer lines together with night setting and integrated-weight longlines (Robertson et al. 2006) could significantly contribute to a reduction in the incidental capture of White-chinned Petrels (among other Procellariiform birds) by Argentinean longliners.

\section{Acknowledgements}

We are very grateful to R. Mariano y Jelicich, G. Blanco, M. P. Silva Rodriguez, G. Cañete, A. Arias, H. Brachetta and G. García for their assistance and cooperation through the different stages of this study. We express our gratitude to all the observers from the National Observers Program (INIDEP). This work was partially supported by the University of Mar del Plata (Grant 15/E238) and Fundación Antorchas (Grant 13900/13).

\section{References}

Acha, E. M., Mianzan, H. W., Guerrero, R. A., Favero, M. and Bava, J. (2004) Marine fronts at the continental shelves of austral South America: physical and ecological processes. J. Mar. Syst. 44: 83-105.

Alexander, K., Robertson, G. and Gales, R. (1997) The incidental mortality of albatrosses in longline fisheries. Workshop Report. First International Conference on the Biology and Conservation of Albatrosses. Hobart, Australia.

Ashford, J. R., Croxall, J. P., Rubilar, P. S. and Moreno, C. A. (1995) Seabird interactions with longlining operations for Dissostichus eleginoides around South Georgia, April to May 1994. CCAMLR Science 2: 111-121.

Barnes, K. N., Ryan, P. G. and Boix-Hinzen, C. (1997) The impact of the hake Merluccius spp. longline fishery off South Africa on procellariiform seabirds. Biol. Conserv. 87: 227-234.

Berrow, S. D. and Croxall, J. P. (1999) The diet of White-chinned Petrels Procellaria aequinoctialis, Linnaeus 1758 , in years of contrasting prey availability at South Georgia. Antarct. Sci. 11: 283-292.

Berrow, S. D., Croxall, J. P. and Grant, S. D. (2000a) Status of White-chinned Petrels Procellaria aequinoctialis Linnaeus 1758, at Bird Island, South Georgia. Antarct. Sci. 12: 399-405.

Berrow, S. D., Wood, A. G. and Prince, P. A. (20oob) Foraging location and range of White-chinned Petrels Procellaria aequinoctialis breeding in the South Atlantic. J. Avian Biol. 31: 303-311.

Birdlife International (2004) Threatened birds of the world 2004. CD-ROM. Cambridge, U.K.: Birdlife International.

Brothers, N. (1991) Albatross mortality and associated bait loss in the Japanese longline fishery in the Southern Ocean. Biol. Conserv. 55: 255-268.

Brothers, N. P., Cooper, J. and Løkkeborg, S. (1999) The incidental catch of seabirds by longline fisheries: worldwide review and technical guidelines for mitigation. FAO Fisheries Circular No. 937. Rome: FAO.

Cherel, Y., Weimerskirch, H. and Duhamel, G. (1996) Interactions between longline vessels and seabirds in Kerguelen waters and a method to reduce seabird mortality. Biol. Conserv. 75: 63-70.

Favero, M., Khatchikian, C. E., Arias, A., Silva Rodríguez, M. P., Cañete, G. and Mariano-Jelicich, R. (2003) Estimates of seabird by-catch along the Patagonian Shelf by Argentine longline fishing vessels: 1999-2001. Bird Conserv. Int. 13: 273-281.

Gómez Laich, A., Favero, M., MarianoJelicich, R., Blanco, G., Cañete, G., Arias, A., Silva Rodríguez, P. and Brachetta, H. (2006) Environmental and operational variability affecting the mortality of Black-browed Albatrosses associated to longliners in Argentina. Emu 106: 21-28.

Huin, N. (1994) Diving depths of Whitechinned Petrels. The Condor 96: IIII-III3. 
Klaer, N. and Polacheck, T. (1998) The influence of environmental factors and mitigation measures on by-catch rates of seabirds by Japanese longline fishing vessels in the Australian region. Emu 38: 305-316.

Kock, K. H. (2001) The direct influence of fishing and fishery-related activities on non-target species in the Southern Ocean with particular emphasis on longline fishing and its impact on albatrosses and petrels: a review. Rev. Fish Biol. Fisher. 11: $31-56$.

Løkkeborg, S. (1998) Seabird by-catch and bait loss in long-lining using different setting methods. ICES J. Mar. Sci. 55: 145-149.

McCullagh, P. and Nelder, J. A. (1983) Generalized linear models. Monographs on statistics and probability. London: Chapman and Hall.

Neves, T. and Olmos, F. (1997) Albatross mortality in fisheries off the coast of Brazil. Pp. 214-219 in G. Robertson and R. Gales, eds. Albatross biology and conservation. Australia: Surrey Beatty and Sons.

Olmos, F., Silva Neves, T. and Vooren, C. M. (2000) Spatio-temporal distribution of
White-chinned Procellaria aequinoctialis and Spectacled P. conspicillata Petrels off Brasil. In E. Flint and K. Swift, eds. Second International Conference on the Biology and Conservation of Albatrosses and other Petrels, Honolulu, Hawaii, Mar. Ornithol. 28: Pp. 125-152.

Phillips, R. A., Silk, J. R. D., Croxall, J. P. and Afanesyeu, V. (2006) Year-round distribution of White-chinned petrels from South Georgia: relationships with oceanography and fisheries. Biol. Conserv. 129: 336-347.

Robertson, G., McNeill, M., Smith, N., Wienecke, B., Candy, S. and Olivier, F. (2006) Fast sinking (integrated weight) longlines reduce mortality of Whitechinned Petrels (Procellaria aequinoctialis) and Sooty Shearwaters (Puffinus griseus) in demersal longline fisheries. Biol. Conserv. 132: 458-471.

Warham, J. (1990) The petrels: their ecology and breeding systems. London: Academic Press.

Weimerskirch, H., Catard, A., Prince, P. A., Cherel, Y. and Croxall, J. (1999) Foraging White-chinned petrels Procellaria aequinoctialis at risk: from the tropics to Antarctica. Biol. Conserv. 87: 273-275.

\section{AGUSTINA GÓMEZ LAICH}

Universidad Nacional de Mar del Plata, Facultad Ciencias Exactas y Naturales, Departamento Biología, Funes 3250 (B7602AYJ) Mar del Plata, Argentina.

\section{MARCO FAVERO*}

Universidad Nacional de Mar del Plata, Facultad Ciencias Exactas y Naturales, Departamento Biología, Funes 3250 (B7602AYJ) Mar del Plata, Argentina.

Consejo Nacional de Investigaciones Científicas y Técnicas (CONICET), Av. Rivadavia 1917 (C1033AAJ), Buenos Aires, Argentina.

*Author for correspondence; e-mail:mafavero@mdp.edu.ar 